\title{
PEMBERDAYAAN PERANGKAT DESA DALAM PENYAMPAIAN INFORMASI PUBLIK UNTUK MENCEGAH KORUPSI DALAM PELAKSANAAN PROGRAM BUMDES DI DESA GENDRO - KABUPATEN PASURUAN
}

\author{
Rachmat Kriyantono $^{1)}$, Yun Fitrahyati Laturrakhmi' ${ }^{2}$; Sinta Swastikawara ${ }^{3)}$ \\ Azizun Kurnia Illahi ${ }^{4)}$, Dessanti Putri Sekti Ari ${ }^{5)}$ \\ ${ }^{1,2,3.4)}$ Fakultas Ilmu Sosial dan Ilmu Politik, Universitas Brawijaya \\ ${ }^{5)}$ Fakultas Ilmu Administrasi, Universitas Brawijaya \\ e-mail: rachmat_kr@ub.ac.id ${ }^{1)}$
}

\begin{abstract}
Abstrak
Perangkat desa sebagai pemerintahan kecil di tingkat desa, sepatutnya paham tentang kewajiban mereka, utamanya terkait keterbukaan arus informasi dari perangkat desa ke masyarakat dan begitu pula sebaliknya. Hal ini nyatanya banyak ditemukan oleh tim di lapangan, salah satunya adalah di Desa Gendro Kabupaten Pasuruan. Data menunjukkan bahwa perangkat desa menganggap bahwa peran mereka sebagai perangkat desa telah berjalan sesuai dengan yang ditugaskan kepada mereka. Mereka mengakui bahwa terdapat tupoksi ganda yang mereka lakukan, namun itu semua dilakukan untuk membantu rekan mereka yang mengalami kesulitan. Di sisi lain, perangkat desa juga merasa bahwa ada kelompok di masyarakat yang tidak percaya dengan kinerja perangkat desa namun tidak disampaikan secara langsung kepada perangkat desa. Hubungan antara perangkat desa dengan organisasi lain di dalam desa seperti PKK, BPD, Karang Taruna juga ikut merasakan bahwa perangkat desa menutup pintu untuk melakukan komunikasi, baik dengan masyarakat maupun dengan organisasi lain di dalam desa. Oleh karena itu, kegiatan pengabdian masyarakat ini banyak difokuskan pada pemberian pemahaman kepada perangkat desa Gendro dalam meningkatkan pemahaman mereka atas pengelolaan keterbukaan informasi publik dan pengelolaan dana desa.
\end{abstract}

Kata Kunci : Informasi Publik, Perangkat Desa, Pencegahan Korupsi

\section{PENDAHULUAN}

Wilayah Kabupaten Pasuruan merupakan wilayah dengan jumlah desa yang cukup besar, yaitu sejumlah 273 desa (Radar Bromo, 2016). Berdasarkan besaran tersebut, perkembangan desa masih menjadi permasalahan yang sering ditemui di wilayah Kabupaten Pasuruan. Dalam beberapa tahun terakhir ini, permasalahan yang dihadapi cukup besar bagi pemerintah Kabupaten Pasuruan adalah korupsi dana desa. Berdasarkan data yang diperoleh dari Dinas Pemberdayaan Masyarakat dan Desa Kabupaten Pasuruan, pada tahun 2018 ini saja sudah terjadi pergantian Kepala Desa di 2 wilayah karena ditemukannya permasalahan korupsi dana desa yang dilakukan oleh Kepala Desa setempat. Dua wilayah yang pada tahun 2018 ini terindikasi melakukan korupsi dana desa adalah Desa Watu Kosek, Kecamatan Gempol dan Desa Sekarputih, Kecamatan Prigen.

Permasalahan korupsi yang terjadi pada beberapa desa di Kabupaten Pasuruan, menunjukkan adanya kesamaan, yaitu dilakukan oleh Kepala Desa selaku penerima dana desa. Oleh sebab itu, implementasi Program BUMDES sebagai satu dari empat program unggulan Kementerian Desa PDDT yang dicanangkan sejak tahun 2017 menuntut adanya kesiapan dari desa, termasuk mekanisme penyampaian informasi kepada masyarakat terkait penggunaan dana desa. Berdasarkan peraturan pemerintah melalui Undang-undang Desa Nomor 6 Tahun 2016, porsi dana BUMDES dapat diletakkan pada porsi Pemberdayaan, terutama bagi desa yang masih belum memiliki BUMDES. Selain sebagai dana untuk pemberdayaan, dana desa juga digunakan sebagai dana pembangunan dan dana untuk gaji perangkat desa. Hal yang menjadi penting pada dana milik desa ini adalah pengelolaannya ada di bawah kendali kepala desa.

Akan tetapi, permasalahan yang seringkali muncul adalah tidak setiap kepala desa memahami bahwa anggaran dana desa dan dana BUMDES yang dikucurkan oleh pemerintah melalui kepala desa merupakan dana yang seharusnya dikelola untuk masyarakat desa. Berdasarkan informasi yang diperoleh dari tim ahli Dinas Pemberdayaan Masyarakat dan Desa Kabupaten Pasuruan, Kepala Desa yang melakukan korupsi umumnya memiliki kesamaan masalah yaitu:

1. Rendahnya pemahaman kepala desa tentang peraturan penggunaan dana desa, dana BUMDES, 
pembagian dan peruntukannya, serta pemahaman terkait penyelenggaraan pemerintah desa.

2. Rendahnya kualitas sumber daya manusia Kepala Desa yang ada di wilayah Kabupaten Pasuruan. Hal ini dilihat dari dibutuhkannya Ujian Akademik khusus bagi Bakal Calon Kepala Desa yang diadakan secara khusus oleh Kabupaten Pasuruan.

3. Pengelolaan dana desa yang tidak transparan. Dalam hal ini, mayoritas wilayah desa di Kabupaten Pasuruan masih banyak belum melakukan transparansi penggunaan dana desa.

4. Pengelolaan dana BUMDES yang tidak transparan. Berkaitan dengan dana BUMDES, pada hakikatnya dana BUMDES merupakan dana yang dikelola secara mandiri oleh masyarakat dan penggunaannya diawasi oleh Kepala Desa. Namun pada kenyataannya, pengelolaan dana BUMDES cenderung dikuasai oleh Kepala Desa.

Permasalahan kedua terkait hal ini adalah kemampuan masyarakat untuk mengakses informasi terkait penggunaan dana desa dan dana BUMDES. Berdasarkan informasi yang juga diperoleh melalui tim ahli Dinas Pemberdayaan Masyarakat dan Desa menunjukkan bahwa:

1. Staf pada badan pemerintah desa yang bertugas untuk mengelola dana BUMDES adalah orangorang yang memiliki pengaruh bagi masyarakat desa. Hal ini akan bernilai positif jika yang diletakkan pada posisi tersebut adalah orang yang dianggap memiliki pengaruh positif bagi masyarakat. Namun, permasalahan yang selalu ditemukan di lapangan adalah posisi pengelola dana BUMDES adalah orang yang memiliki pengaruh negatif pada masyarakat dan menjadi kaki tangan bagi kepala desa.

2. Dengan keberadaan staf perangkat desa sebagai pengelola dana BUMDES yang ditakuti oleh masyarakat desa, maka kecenderungan masyarakat desa untuk mampu mengakses informasi dana BUMDES menjadi rendah. Masyarakat akan cenderung pasif dan tidak berani terhadap perangkat desa tersebut.

Berdasarkan kedua masalah utama yang telah dipetakan di atas, maka dapat disimpulkan bahwa ada beberapa kecenderungan terkait posisi kepala desa sebagai posisi sentral dalam berjalannya pemerintahan desa. Satu, Kepala Desa tidak mengetahui dan tidak teredukasi terkait penggunaan dana BUMDES, baik yang terkait tata kelola keuangan hingga pada tata kelola pemerintahan. Dua, Kepala Desa yang cenderung tidak memberikan akses informasi bagi masyarakat, dengan kata lain tidak terbuka, umumnya memiliki kecenderungan negatif. Hal ini dibuktikan dengan keberadaan 2 desa yang memiliki kepala desa koruptor, terindikasi bahwa mereka tidak pernah terbuka dalam pengelolaan dana BUMDES.

Jika dilihat berdasarkan Indeks Desa Membangun (IDM), secara umum data tahun 2015 menunjukkan bahwa secara umum desa-desa di wilayah Kabupaten Pasuruan dapat dikategorikan ke dalam Desa Berkembang (Desa Madya) dengan indeks desa membangun sebesar 0.6292. Dengan menggunakan parameter ini, potensi permasalahan tersebut dapat dikaitkan dengan indeks ketahanan sosial, khususnya dalam dimensi modal sosial.

Berdasarkan Permendesa Nomor 2 Tahun 2016 tentang Indeks Desa Membangun (IDM), berdasarkan klasifikasi status desa terdapat 5 kategori desa yaitu desa mandiri (desa sembada), desa maju (desa pra-sembada), desa berkembang (desa madya), desa tertinggal (pra-madya), dan desa sangat tertinggal (pratama). Data tahun 2016 menunjukkan bahwa jumlah tertinggi desa di Indonesia adalah desa dengan status tertinggal (45.57\%). Data Kementerian Desa, Pembangunan Daerah Tertinggal dan Transmigrasi (2015) menunjukkan bahwa secara umum desa-desa di Kabupaten Pasuruan memiliki indeks desa membangun sebesar 0.6292 sehingga terkategori dalam desa berkembang (desa madya). Sementara itu, data spesifik tentang IDM pada Desa Gendro, Kecamatan Tutur, Kabupaten Pasuruan tidak dapat ditelusuri. Dengan demikian, jika meminjam IDM rata-rata yang berlaku pada desa-desa di wilayah Kabupaten Pasuruan, dapat diargumentasikan bahwa Desa Gendro termasuk ke dalam kategori desa berkembang (desa madya).

Berdasarkan hasil wawancara dengan salah satu tokoh masyarakat Desa Gendro (2018), ditemukan bahwa perpustakaan desa semula ada meski cenderung pasif dalam pelayanan pada masyarakat. Namun, ketidakpuasan masyarakat pada kepemimpinan kepala desa pada tahun 2009 membuat fasilitas umum di Balai Desa Gendro menjadi sasaran amukan warga. Permasalahan tentang rendahnya kepercayaan publik mewarnai kepemimpinan kepala desa periode 2009-2015. Bibitbibit ketidakpercayaan publik masih terlihat pada pemerintahan Kepala Desa Gendro periode 20152021. Jika mengacu pada indikator pengukuran indeks ketahanan sosial, maka hal ini berkaitan dengan dimensi modal sosial khususnya pada indikator solidaritas sosial dan rasa aman.

Menyikapi rendahnya kepercayaan publik, pemerintah Desa Gendro menginisiasi pemberian laporan penggunaan dana desa yang disampaikan 
secara rutin satu tahun sekali dalam forum praLPJKD (laporan pertanggung jawaban kepala desa). Hasil wawancara dengan Sekretaris Desa Gendro dan Kaur Keuangan Desa Gendro (April 2018), mengungkap bahwa laporan tersebut disampaikan kepada warga dengan media dokumen tertulis melalui Ketua RT RW dan kepala dusun di lingkungan Desa Gendro. Akan tetapi, media penyampaian ini dipandang tidak efektif karena faktor usia dan rendahnya kualitas SDM dari kalangan Ketua RT/RW maupun kepala dusun, sehingga informasi tidak sampai pada warga masyarakat. Di samping penggunaan media dalam bentuk dokumen tertulis, laporan penggunaan dana desa pernah disampaikan secara tertulis melalui media banner yang dipasang di depan Balai Desa Gendro. Namun, sekali lagi media tersebut justru dirusak karena dianggap tidak sesuai dengan kondisi riil (wawancara dengan Kaur Keuangan Desa Gendro).

Oleh sebab itu, dibutuhkan sebuah sistem tata kelola komunikasi yang dapat secara efektif menjembatani masyarakat dan pemerintah Desa Gendro dalam penyampaian informasi publik, khususnya tentang penggunaan dana desa. Sistem ini diharapkan dapat memunculkan kepercayaan masyarakat pada pemerintah desa, memenuhi hak publik untuk mengetahui serta menghindari terjadinya korupsi sebab memungkinkan terwujudnya transparansi pengelolaan anggaran. Terlebih pemerintah Desa Gendro sedang dalam persiapan implementasi Program Bumdes yang banyak berkaitan dengan pengelolaan dana desa.

Buruknya kualitas komunikasi internal antar perangkat desa disebabkan pula oleh rendahnya SDM yang menduduki posisi perangkat desa. Rendahnya kualitas SDM membawa pada kerancuan pola kerja akibat ketidakpahaman atas job-description dan penentuan prioritas pekerjaan. Hasil penelusuran data awal mengungkap bahwa dari 6 perangkat desa, hanya 3 orang yang mempunyai kemampuan mengoperasikan komputer. Dari sisi alur komunikasi, ditemukan masalah berupa tidak berlakunya aliran informasi sesuai dengan posisi dan pembagian tugas. Jaringan komunikasi yang terbentuk justru hanya berdasarkan kepentingan dan senioritas saja. Oleh sebab itu, diperlukan sistem tata kelola komunikasi internal yang menjamin arah aliran informasi berjalan lebih baik, sesuai dengan pembagian pekerjaan untuk menghindari pengumpulan informasi di titik tertentu yang pada akhirnya dapat memunculkan potensi penyalahgunaan wewenang karena mekanisme kontrol yang seharusnya dipegang Sekretaris Desa tidak berjalan optimal.

\section{METODE KEGIATAN}

Berdasarkan hasil analisis situasi dan permasalahan mitra, sebagaimana telah dipaparkan sebelumnya bahwa Desa Gendro belum memiliki mekanisme penyampaian informasi yang efektif kepada masyarakat dan pemilihan media informasi pengelolaan dana hingga berdampak pada munculnya penolakan hingga kecurigaan masyarakat, terlebih diperparah dengan rendahnya kualitas SDM perangkat desa serta buruknya aliran komunikasi internal dalam organisasi pemerintah, membuat persiapan pelaksanaan Program Bumdes (Badan Usaha Milik Desa) di Desa Gendro belum dapat terlaksana dengan baik.

Berkaca dari persoalan tersebut, solusi yang dapat diberikan berupa Pemberdayaan Perangkat Desa melalui pembenahan sistem tata kelola komunikasi, baik secara internal maupun eksternal dalam pemenuhan dan implementasi dari Keterbukaan Informasi Publik yang erat kaitannya dengan pelaksanaan good governance. Di samping itu, akan dilakukan pula pendampingan untuk memunculkan pemahaman perangkat desa tentang informasi yang harus disampaikan pada publik dan informasi yang tidak disampaikan kepada publik. Dengan demikian, diharapkan dapat tercipta sistem yang efektif dalam pelaksanaan Program BUMDES dan mencegah terjadinya korupsi. Urgensi pemilihan Desa Gendro berkaitan dengan kondisi bahwa desadesa di wilayah Kabupaten Pasuruan rentan terjadi korupsi dana desa, sebagaimana telah terjadi pada 2 desa di wilayah Kabupaten Pasuruan pada awal 2018.

Seperti yang diketahui bahwa Keterbukaan Informasi Publik saat ini menjadi salah satu tuntutan dari perbaikan sistem kepemerintahan pasca reformasi. Masyarakat menilai bahwa sebuah kepemerintahan dapat dinilai baik adalah adanya tata kelola pemerintahan yang baik mensyaratkan adanya akuntabilitas, transparansi dan partisipasi masyarakat dalam setiap setiap proses terjadinya kebijakan publik. Adanya tuntutan tersebut maka lahirlah Undang-undang Republik Indonesia Nomor 14 Tahun 2008 Tentang Keterbukaan Informasi Publik. Secara spesifik, Undang-undang Keterbukaan Informasi Publik ini muncul dikarenakan pemerintah pun menyadari bahwa informasi merupakan kebutuhan pokok setiap orang, guna mengembangkan potensi pribadi dan lingkungan sosial serta merupakan bagian penting bagi ketahanan nasional.

Keterbukaan informasi publik juga merupakan sarana dalam mengoptimalkan pengawasan publik terhadap penyelenggaraan negara dan badan publik lainnya dan segala sesuatu yang berakibat pada 
kepentingan publik (Undang-Undang KIP Nomor 14 tahun 2008). Astuti dan Erman (2016) menjelaskan bahwa Informasi publik ini dapat dimohonkan kepada lembaga-lembaga publik, baik itu Lembaga/Badan Pemerintah maupun Non-Pemerintah selama lembaga/badan tersebut mengelola atau menggunakan dana APBN/APBD, sumbangan masyarakat dan atau sumbangan dari luar negeri baik itu informasi keuangan, pengambilan keputusan atau yang lainnya kecuali informasi yang dikecualikan sebagaimana telah diatur dalam UU KIP tersebut.

Melalui kegiatan Doktor Mengabdi ini tim pengusul ingin memberikan solusi yang konkret dengan melakukan pemberdayaan perangkat desa melalui pembenahan sistem tata kelola komunikasi baik Internal maupun ekstenal serta melakukan pendampingan guna memunculkan pemahaman perangkat desa tentang informasi publik. Ada pun bentuk kegiatan untuk pengimplementasian dari solusi yang ditawarkan adalah sebagai berikut :

1. Melakukan FGD untuk pemetaan agar memahami permasalahan mengenai :

a) Alur komunikasi secara internal (sesama perangkat desa) dan eksternal (dari perangkat desa kepada masyarakat)

b) Potensi jaringan komunikasi yang terdapat dalam perangkat desa maupun dengan kepala dusun, ketua RT/RW dan kepala dusun

c) Perilaku penggunaan informasi di kalangan masyarakat

d) Mekanisme penyaluran informasi pada masyarakat dari perangkat desa

2. Pendidikan dan Pelatihan (diklat) untuk mengedukasi dan memperkenalkan pemahaman tentang keterbukaan informasi publik, khususnya kewajiban penyampaian informasi pengelolaan dana desa pada masyarakat. Kegiatan diklat tersebut dibagi menjadi beberapa langkah berikut ini :

a) Sosialisasi tupoksi setiap bagian dalam perangkat desa dan konsekuensi arah aliran informasi

b) Sosialisasi Undang-Undang Keterbukaan Publik dan konsekuensi penerapan UU tersebut dalam implementasi program desa, termasuk BUMDES

c) Sosialisasi Implementasi Program Bumdes dan mekanisme pengelolaan dana desa

d) Pengenalan dan pelatihan sistem komunikasi internal yang lebih efektif

e) Pengenalan dan pelatihan sistem komunikasi eksternal yang lebih efektif
3. Simulasi dan pendampingan mekanisme pelaporan dana semester awal 2018 dan evaluasi penerapan program

Adapun peta jalan (roadmap) pengabdian tim pengusul untuk desa mitra secara skematis tergambar sebagai berikut :

\section{Bagan Roadmap Pengabdian Massarakat}

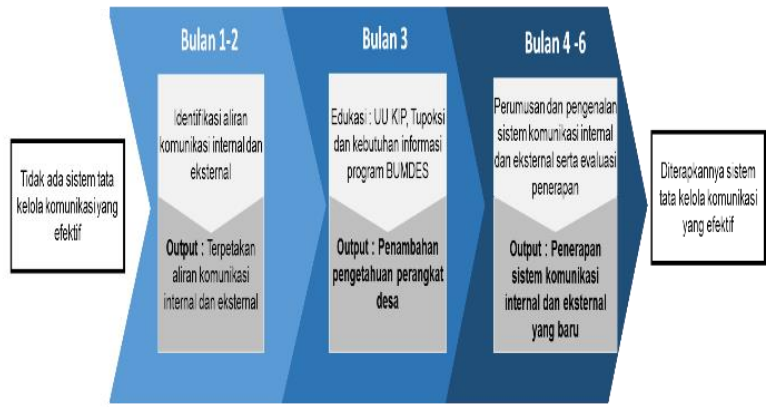

Gambar 1. Roadmap Pengabdian Masyarakat

Berangkat dari identifikasi permasalahan mitra dan rancangan solusi yang ditawarkan, target luaran dari pengabdian masyarakat ini yaitu :

1. Berlakunya sistem tata kelola komunikasi internal dan eksternal yang lebih efektif dan solutif khususnya terkait penyampaian informasi pengelolaan dana desa.

2. Peningkatan pengetahuan perangkat desa tentang job description dan arah aliran komunikasi dan koordinasi antar bagian dalam pemerintahan desa.

3. Peningkatan pengetahuan perangkat desa tentang informasi yang wajib disampaikan kepada masyarakat dan informasi yang tidak dapat disampaikan kepada masyarakat (publik).

4. Peningkatan transparansi informasi eksternal yang ditunjukkan oleh peningkatan frekuensi pelaporan pengelolaan dana desa dan peningkatan keberagaman media pelaporan yang tepat sasaran dan sesuai dengan karakteristik masyarakat desa.

\section{HASIL DAN PEMBAHASAN}

Sebagaimana telah dipaparkan sebelumnya, bahwa terdapat beberapa tahapan yang dilakukan tim dalam upaya pemberdayaan perangkat Desa Gendro dalam penyampaian informasi publik terkait pelaksanaan Program BUMDES. Ketiga tahapan tersebut yaitu: (1) identifikasi terhadap aliran komunikasi internal dan eksternal; (2) Edukasi tentang UU KIP, tupoksi masing-masing perangkat desa, dan kebutuhan informasi Program BUMDES, serta (3) perumusan dan pengenalan sistem komunikasi internal dan eksternal. 


\subsection{Identifikasi Terhadap Aliran Komunikasi Internal dan Eksternal}

\section{a) Identifikasi Aliran Komunikasi Internal: antar Perangkat Desa}

Telah dilakukan proses wawancara terhadap para Perangkat Desa, hasil dari wawancara tersebut adalah bahwa aliran komunikasi secara internal tidak terdapat permasalahan, bahkan cenderung berjalan dengan lancar dan baik. Koordinasi, kerjasama dan hubungan yang terjadi antara perangkat satu dengan perangkat lainnya juga berjalan dengan lancar. Hal tersebut dikarenakan seluruh perangkat desa memahami apa yang menjadi Tupoksi (Tugas Pokok dan Fungsi) yang masing-masing perangkat desa.

Namun, terdapat perbedaan hubungan antara perangkat desa dengan kepala desa saat ini yang menjelaskan bahwa hubungannya dengan perangkat desa lain memang berjalan dengan baik akan tetapi hubungannya dengan kepala desa tidaklah sebaik hubunganya dengan kepala desa yang lama. Muncul juga permasalahan lain terkait beberapa perangkat desa yang ditempatkan pada posisi yang itu bukan bidangnya. Sehingga perangkat desa tersebut tidak dapat menjalankan Tupoksinya dengan baik.

\section{b) Identifikasi Aliran Komunikasi Eksternal: Perangkat Desa dengan Masyarakat}

Berdasarkan hasil wawancara menunjukkan bahwa masyarakat selama ini tidak paham dengan kinerja yang telah diupayakan oleh perangkat desa, termasuk permasalahan pengelolaan dana desa. Perangkat desa memandang bahwa sikap masyarakat yang hanya selalu bergunjing di belakang mereka menjadikan upaya mereka untuk memberikan pemahaman terhadap masyarakat menjadi tidak berguna. Sayangnya hal ini tidak diiringi dengan upaya perangkat desa untuk memberikan informasi terkait penggunaan dana desa berikut dengan pajak yang harus dibayarkan. Prasangka masyarakat kepada perangkat desa semakin terbetuk diakibatkan rendahnya saluran komunikasi yang tercipta antara perangkat desa dengan masyarakat.

Di sisi lain kepala desa meyakini bahwa kinerjanya selama ini sudah cukup baik terutama jika dikaitkan dengan hubungan antara perangka desa dengan masyarakat. Ia menyoroti pada perannya sebagai kepala desa yang selalu rutin untuk mengunjungi wilayah dusun. Dengan kegiatannya tersebut, ia menilai bahwa banyak keuntungannya salah satunya ia tahu bahwa ada kondisi perekonomian yang tidak merata yang ia nilai melalui kelayakan tempat tinggal. Kepala desa juga menilai bahwa latar belakang ia sebagai santri menjadi modal yang kuat untuk menjalin hubungan yang lebih baik dengan masyarakat.

Perbedaan pandangan antar perangkat desa terkait hubungan perangkat desa dengan masyarakat, jika merujuk pada data yang telah diperoleh, dapat dilihat dalam 2 kategori. kategori pertama, perangkat desa menilai bahwa hubungan mereka dengan masyarakat tidak baik jika didasarkan pada pembahasan keuangan desa, dalam artian masyarakat merasa tidak percaya sepenuhnya pada perangkat desa atas pengelolaan dana desa yang digunakan dalam pembangunan fisik dan pendanaan kegiatan lembaga desa. Kategori kedua, perangkat desa menilai bahwa hubungan mereka dengan masyarakat baik jika dibandingkan dengan perangkat desa sebelumnya, dalam artian bahwa perangkat desa menilai hubungan antara dirinya dengan masyarakat jauh lebih akrab jika dibandingkan dengan perangkat desa yang sebelumnya.

\section{c) Identifikasi Aliran Komunikasi Eksternal: Perangkat Desa dengan Lembaga Desa serta antar-lembaga}

Hasil FGD di lapangan menunjukkan hasil yang cukup berbeda antara cara pandang beberapa lembaga desa terhadap komunikasi dan koordinasi yang dijalani dengan perangkat desa. Secara umum, BPD dan Karang Taruna menilai adanya permasalahan dalam aliran komunikasi lembaga mereka dengan perangkat desa, sedangkan PKK dan LPM tidak melihat adanya hambatan komunikasi sebagaimana dialami BPD dan Karang Taruna. Bagi informan yang merupakan perwakilan dari LPM, komunikasi dan koordinasi antara lembaga mereka dengan perangkat desa sudah dilakukan.

Akan tetapi, LPM lebih banyak menggarisbawahi perlunya fungsi penyaring informasi dalam upaya mengomunikasikan pelaksanaan program serta pelaporan pengelolaan dana desa dari perangkat desa kepada masyarakat. Perwakilan LPM juga menekankan pentingnya koordinasi antar bagian dalam tubuh perangkat desa sendiri mengingat karakteristik masyarakat Desa Gendro yang didominasi oleh masyarakat dengan latar belakang pendidikan rendah membutuhkan treatement khusus dalam proses penyampaian program ataupun pelaporan keuangan desa. 
Tabel 1. Temuan Kunci terkait Aliran Komunikasi Eksternal: Perangkat Desa dengan Lembaga Desa di luar Perangkat Desa

\begin{tabular}{|c|c|c|}
\hline Aspek & BPD & Karang Taruna \\
\hline Keanggotaan & $\begin{array}{l}\text { Terdiri atas } \\
\text { perwakilan masing- } \\
\text { masing dusun, namun } \\
\text { tidak semua anggota } \\
\text { BPD memiliki } \\
\text { kompetensi yang } \\
\text { cukup. }\end{array}$ & $\begin{array}{l}\text { Terdiri atas } 4-5 \text { orang per- } \\
\text { dusun, sehingga total } \\
\text { terdapat } 25 \text { anggota dari } \\
\text { unsur pemuda. Sebagian } \\
\text { besar pemuda memiliki } \\
\text { kualitas SDM yang rendah } \\
\text { namun sangat kompak. }\end{array}$ \\
\hline $\begin{array}{l}\text { Tujuan dan } \\
\text { kegiatan } \\
\text { utama }\end{array}$ & $\begin{array}{l}\text { - Bertujuan } \\
\text { membangun } \\
\text { pemerintahan desa } \\
\text { yang lebih terbuka, } \\
\text { transparan } \\
\text { - Melakukan kontrol } \\
\text { dan evaluasi } \\
\text { terhadap kinerja } \\
\text { perangkat desa } \\
\text { - Menjalin } \\
\text { komunikasi dan } \\
\text { menjamin } \\
\text { ketersediaan } \\
\text { informasi yang } \\
\text { cukup antara BPD } \\
\text { dan perangkat desa } \\
\text { serta masyarakat }\end{array}$ & $\begin{array}{l}\text { - Bertujuan memberikan } \\
\text { ruang bagi masyarakat } \\
\text { untuk menyampaikan } \\
\text { aspirasinya dan } \\
\text { memastikan terciptanya } \\
\text { pemerintahan desa yang } \\
\text { transparan } \\
\text { - Kegiatan utama adalah } \\
\text { kegiatan pemberdayaan } \\
\text { pemuda. Pada tahun } \\
\text { 2013 - 2016, dilakukan } \\
\text { kemitraan dengan pabrik } \\
\text { untuk usaha penjualan } \\
\text { pupuk. Namun, hingga } \\
\text { saat ini belum ada } \\
\text { realisasi dari rencana } \\
\text { pengelolaan sampah, } \\
\text { terhambat oleh } \\
\text { koordinasi dengan } \\
\text { perangkat desa } \\
\text { - Banyak melakukan } \\
\text { kegiatan informal seperti } \\
\text { kegiatan keagamaan dan } \\
\text { kegiatan olahraga }\end{array}$ \\
\hline $\begin{array}{l}\text { Cara } \\
\text { pandang } \\
\text { terhadap } \\
\text { aliran } \\
\text { komunikasi } \\
\text { perangkat } \\
\text { desa dengan } \\
\text { lembaga }\end{array}$ & $\begin{array}{l}\text { Terhambat, proses } \\
\text { komunikasi } \\
\text { dilakukan melalui } \\
\text { pendekatan pada } \\
\text { kepala desa }\end{array}$ & $\begin{array}{l}\text { Terhambat, proses } \\
\text { komunikasi dilakukan } \\
\text { dengan masuk melalui } \\
\text { sekretaris desa }\end{array}$ \\
\hline $\begin{array}{l}\text { Penilaian } \\
\text { terhadap } \\
\text { kinerja } \\
\text { perangkat } \\
\text { desa }\end{array}$ & $\begin{array}{l}\text { Lebih baik dan lebih } \\
\text { transparan pada tahun } \\
\text { kedua, namun tetap } \\
\text { perlu lebih banyak } \\
\text { turun dan terlibat } \\
\text { pada berbagai } \\
\text { kegiatan masyarakat } \\
\text { serta sesama } \\
\text { perangkat desa }\end{array}$ & $\begin{array}{l}\text { Lebih baik dan lebih } \\
\text { transparan sejak } \\
\text { terpilihnya sekretaris desa } \\
\text { sebagai representasi dari } \\
\text { pemuda, namun } \\
\text { memandang masih } \\
\text { besarnya jarak antara } \\
\text { perangkat desa dan } \\
\text { masyarakat serta besarnya } \\
\text { kecurigaan pada perangkat } \\
\text { desa. Pandangan bahwa } \\
\text { sebaik-baiknya performa } \\
\text { perangkat desa saat ini } \\
\text { tetap dinilai tidak lebih } \\
\text { baik dibanding } \\
\text { pemerintahan transisi pada } \\
\text { periode sebelumnya. }\end{array}$ \\
\hline $\begin{array}{l}\text { Pendapat } \\
\text { tentang } \\
\text { koordinasi } \\
\text { dengan } \\
\text { masyarakat }\end{array}$ & $\begin{array}{l}\text { Cukup baik, berhasil } \\
\text { mempertemukan } \\
\text { masyarakat dan } \\
\text { perangkat desa dalam } \\
\text { kegiatan pra-LKPJ } \\
\text { dan LKPJ }\end{array}$ & $\begin{array}{l}\text { Menempati posisi sebagai } \\
\text { wadah bagi masyarakat } \\
\text { untuk menyalurkan } \\
\text { aspirasi mengingat } \\
\text { masyarakat Desa Gendro } \\
\text { mayoritas tidak berani } \\
\text { mengemukakan pendapat. }\end{array}$ \\
\hline
\end{tabular}

Tabel 2. Permasalahan Kunci Aliran Informasi dan Komunikasi Perangkat Desa, BPD dan Karang Taruna

\begin{tabular}{|l|l|}
\hline \multicolumn{1}{|c|}{ Perspektif BPD } & \multicolumn{1}{c|}{ Perspektif Karang Taruna } \\
\hline - Ketidakpercayaan & - Ketidakpercayaan pada \\
masyarakat muncul karena & perangkat desa muncul karena \\
kurangnya kegiatan yang & tidak ada lagi wadah yang \\
memungkinkan seluruh & memungkinkan terbangunnya \\
perangkat desa turun ke & komunikasi, koordinasi yang \\
masyarakat & lebih baik antara Karang \\
- Di dalam perangkat desa & Taruna, BPD dan perangkat \\
masih ada kelompok- & desa \\
kelompok yang cenderung & - Memandang bahwa perangkat \\
tertutup & desa enggan terlibat dalam \\
- Dalam upaya membangun & kegiatan kepemudaan \\
komunikasi dengan & - Menganggap bahwa kinerja \\
perangkat desa, BPD & BPD tidak optimal sebagai \\
dituntut lebih aktif mencari & penyalur asiprasi masyarakat \\
informasi namun terdapat & - Penggunaan banner sebagai \\
anggota BPD yang tidak & media penyampai informasi \\
mempunyai kompetensi & dinilai tidak tepat dan tidak \\
dalam menjalankan fungsi & membuka ruang dialog \\
tersebut & Perlunya memanfaatkan \\
& teknologi informasi dan \\
& komunikasi seperti internet \\
& dalam penyampaian program \\
& desa \\
\hline
\end{tabular}

\subsection{Edukasi tentang UU KIP, tupoksi masing-masing perangkat desa, dan kebutuhan informasi Program BUMDES}

Setelah melalui proses penggalian data, diketahui perlunya pemahaman masyarakat ataupun pihak perangkat desa dan lembaga lainnya di tingkat desa tentang batasan serta kewajiban menyampaikan informasi publik di bawah kerangka Undang-undang Keterbukaan Informasi Publik. Oleh sebab itu, edukasi tentang UU KIP dan implikasi penerapannya menjadi penting untuk dilakukan agar tidak terjadi permasalahan dengan mengatasnamakan keterbukaan dan transparansi publik.

Dalam pelaksanaannya, terdapat 2 treatment yang telah dilakukan oleh tim Doktor Mengabdi yaitu edukasi kepada perangkat desa, perwakilan organisasi desa dan perwakilan masyarakat tentang Undang-undang Keterbukaan Informasi Publik, baik dari content undang-undang tersebut maupun dari sisi implikasi penerapan dan pihak-pihak yang dilibatkan. Selain materi tersebut diberikan pula materi tentang pengelolaan dana desa yang juga ditujukan untuk meningkatkan pemahaman perangkat desa, organisasi desa dan masyarakat tentang hal-hal yang berkaitan dengan pengelolaan dana desa. Dalam proses pemberian treatment ini, tim melakukan pengukuran untuk mengetahui ada tidaknya perubahan pengetahuan setelah treatment dilakukan. 
Tabel 3. Analisis Hasil Pre-test pada Perangkat Desa

\begin{tabular}{|c|l|c|c|}
\hline \multirow{2}{*}{ No } & \multicolumn{1}{|c|}{ Pertanyaan } & \multicolumn{2}{c|}{ Respon yang Diberikan } \\
\cline { 3 - 4 } & & Mengetahui & $\begin{array}{c}\text { Tidak } \\
\text { Mengetahui }\end{array}$ \\
\hline 1 & $\begin{array}{l}\text { Pengetahuan umum tentang } \\
\text { UU KIP }\end{array}$ & $0 \%$ & $100 \%$ \\
\hline 2 & $\begin{array}{l}\text { Pemahaman tentang UU } \\
\text { KIP }\end{array}$ & $30 \%$ & $70 \%$ \\
\hline 3 & $\begin{array}{l}\text { Pengetahuan tentang tujuan } \\
\text { diberlakukannya UU KIP }\end{array}$ & $70 \%$ & $30 \%$ \\
\hline 4 & $\begin{array}{l}\text { Pengetahuan tentang perlu } \\
\text { tidaknya KIP di tingkat desa }\end{array}$ & $100 \%$ & $0 \%$ \\
\hline 5 & $\begin{array}{l}\text { Pengetahuan tentang jenis } \\
\text { informasi yang harus } \\
\text { disampaikan dan tidak harus } \\
\text { disampaikan pada } \\
\text { masyarakat }\end{array}$ & $30 \%$ & $70 \%$ \\
\hline 6 & $\begin{array}{l}\text { Pengetahuan tentang } \\
\text { kewajiban aparatur desa } \\
\text { atas informasi yang } \\
\text { diberikan pada masyarakat }\end{array}$ & $0 \%$ & $100 \%$ \\
\hline
\end{tabular}

Tabel 4. Analisis Hasil Post-test pada Perangkat Desa

\begin{tabular}{|c|l|c|c|}
\hline \multirow{2}{*}{ No } & \multicolumn{1}{|c|}{ Pertanyaan } & \multicolumn{2}{c|}{ Respon yang Diberikan } \\
\cline { 3 - 4 } & & Mengetahui & $\begin{array}{c}\text { Tidak } \\
\text { Mengetahui }\end{array}$ \\
\hline 1 & $\begin{array}{l}\text { Pengetahuan umum tentang } \\
\text { UU KIP }\end{array}$ & $100 \%$ & $0 \%$ \\
\hline 2 & $\begin{array}{l}\text { Pemahaman tentang UU } \\
\text { KIP }\end{array}$ & $100 \%$ & $0 \%$ \\
\hline 3 & $\begin{array}{l}\text { Pengetahuan tentang tujuan } \\
\text { diberlakukannya UU KIP }\end{array}$ & $100 \%$ & $0 \%$ \\
\hline 4 & $\begin{array}{l}\text { Pengetahuan tentang perlu } \\
\text { tidaknya KIP di tingkat desa }\end{array}$ & $100 \%$ & $0 \%$ \\
\hline 5 & $\begin{array}{l}\text { Pengetahuan tentang jenis } \\
\text { informasi yang harus } \\
\text { disampaikan dan tidak harus } \\
\text { disampaikan pada } \\
\text { masyarakat }\end{array}$ & $50 \%$ & $50 \%$ \\
\hline 6 & $\begin{array}{l}\text { Pengetahuan tentang } \\
\text { kewajiban aparatur desa atas } \\
\text { informasi yang diberikan } \\
\text { pada masyarakat }\end{array}$ & $50 \%$ & $50 \%$ \\
\hline
\end{tabular}

Berdasarkan hasil post-test pada perangkat desa diketahui bahwa terjadi perubahan pengetahuan sesuai dengan tujuan treatment diberikan. Hasil tersebut menunjukkan bahwa perubahan terbesar terjadi pada pengetahuan masyarakat secara umum tentang UU KIP serta tujuannya. Terdapat pula perubahan pengetahuan tentang jenis informasi yang wajib disampaikan dan jenis informasi yang tidak wajib disampaikan kepada masyarakat. Dengan demikian dapat disimpulkan bahwa tujuan dari pemberian treatment pertama berupa peningkatan pengetahuan aparatur desa tentang UU KIP dan implikasi penerapannya serta tentang pengelolaan dana desa telah tercapai.

\subsection{Perumusan dan Pengenalan Sistem Komunikasi Internal dan Eksternal}

Standar Operasional Prosedur ini dibuat untuk memberikan kronologis penyelesaian pekerjaan untuk memperoleh hasil yang efektif berkaitan dengan Penyampaian Informasi penggunaan Dana Desa. Diharapkan dengan adanya Rancangan Standar Operasional Prosedur ini dapat digunakan dengan baik agar tidak menjadi permasalahan berkenaan dengan keterbukaan informasi kepada publik yang berhubungan dengan penggunaan dana desa, baik untuk pembangunan dan atau pemberdayaan masyarakat desa.

Pelaksanaan pembangunan yang dilaksanakan oleh pemerintah daerah harus diinformasikan termasuk keuangannya kepada masyarakat. Hal itu sebagai wujud transparansi yang merupakan asas dari pengelolaan keuangan desa. Laporan Pertanggungjawaban Realisasi Pelaksanaan APB Desa sesuai ketentuan dan keterbukaan publik diinformasikan kepada masyarakat secara tertulis dengan media informasi yang mudah diakses oleh masyarakat, antara lain papan pengumuman dan media informasi lainnya. Berikut adalah gambar SOP Komunikasi Internal dan Aliran Komunikasi Internal pada perangkat Desa Gendro sesuai dengan kebutuhan situasi di wilayah:
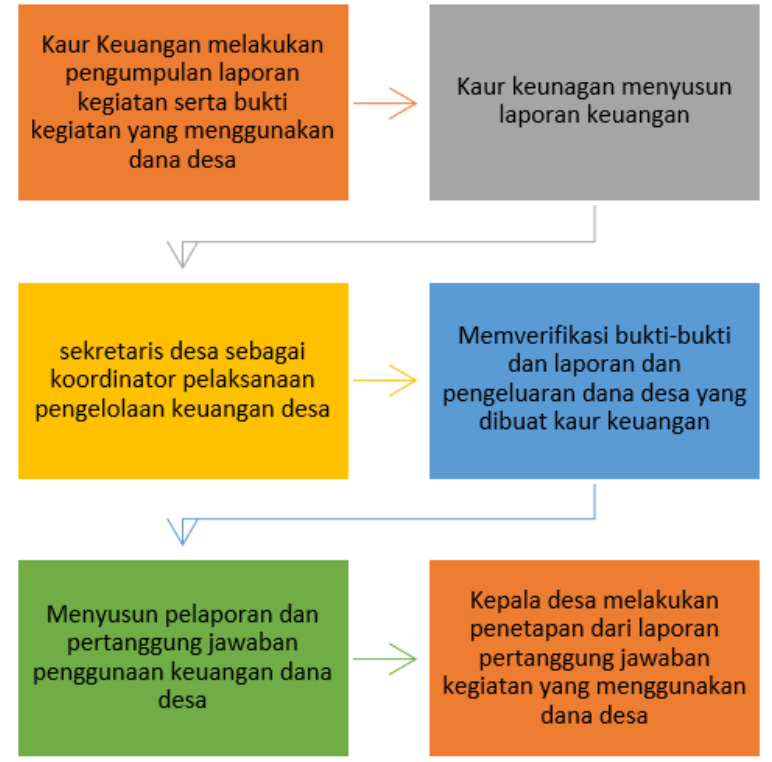

Gambar 2. SOP Komunikasi Internal 


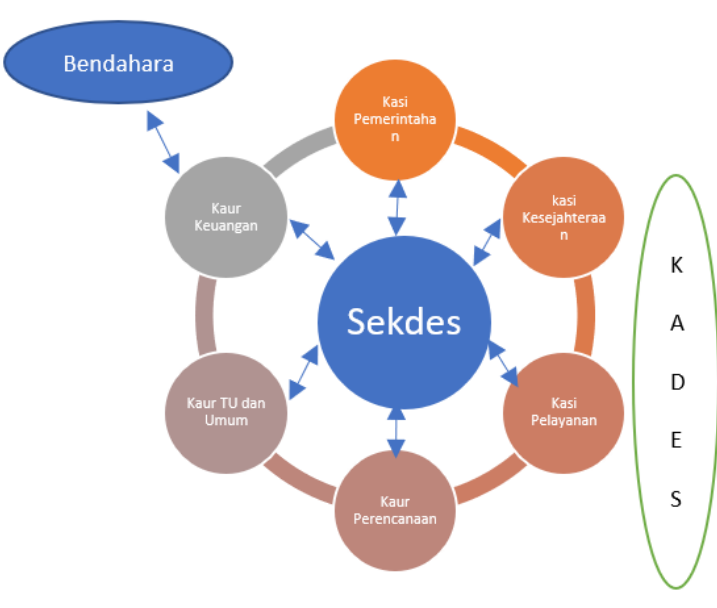

Gambar 3. Aliran Komunikasi Internal Penyampaian Dana Desa

\section{KESIMPULAN}

Hasil identifikasi awal menunjukkan bahwa secara internal, di kalangan perangkat desa sendiri ditemukan kurangnya pemahaman pada tugas, pokok dan fungsi serta kaitannya dengan koordinasi antarperangkat desa. Ditemukan pula bahwa terjadi tumpang tindih aliran informasi antar beberapa bagian karena banyak didasarkan pada preferensi personal. Hal ini menunjukkan perlunya peningkatkan pemahaman perangkat desa tentang tupoksi dan konsekuensi aliran informasi di dalamnya, serta perlunya peningkatan keterbukaan informasi pada beberapa bagian dalam organisasi perangkat desa.

Sementara itu, dalam kaitannya dengan pengetahuan tentang Undang-undang Keterbukaan Informasi Publik serta implikasi penerapannya, diketahui bahwa sebagian besar perangkat desa belum memiliki pengetahuan yang cukup terhadapnya. Kemudian, secara eksternal ditemukan bahwa belum ada media komunikasi yang dapat digunakan secara efektif dalam penyampaian pengelolaan dana desa sehingga memunculkan ketidakpercayaan publik pada pemerintah desa khususnya tentang penggunaan dana desa. Data lapangan juga menunjukkan bahwa kalangan masyarakat sendiri cenderung tidak percaya pada perangkat desa dan menuntut agar pemerintah desa menyediakan segala jenis informasi pada masyarakat. Hal ini mengindikasikan rendahnya pengetahuan masyarakat pada arti dan batasan keterbukaan informasi publik sehingga dibutuhkan edukasi tentang UU KIP serta implikasi penerapannya.

Melalui treatment pertama yang berupa edukasi pada perangkat desa, organisasi desa dan masyarakat diperoleh hasil bahwa terjadi peningkatan pengetahuan terhadap UU KIP, baik dari sisi tujuan, implikasi penerapan serta tentang jenis informasi yang wajib diumumkan secara berkala, informasi yang rahasia dan informasi yang disediakan berdasarkan permintaan. Peningkatan pengetahuan diperoleh dari hasil pengukuran melalui pretest dan post-test. Kemudian, treatment kedua menghasilkan rumusan model komunikasi yang dapat diterapkan perangkat desa sehingga dapat tercipta tata kelola komunikasi internal dan eksternal yang lebih efektif dam mendorong terbangunnya keterbukaan informasi. Berbagai treatment yang telah dilakukan dipandang belum dapat memberikan mekanisme pencegahan dari segala aspek, sehingga dibutuhkan langkah-langkah lanjutan demi terwujudnya pemerintahan desa yang baik, jauh dari potensi korupsi.

\section{REFERENSI}

Febriananingsih, N. (2012). Keterbukaan Informasi Public dalam Pemerintahan Terbuka Menuju Tata Pemerintahan yang Baik: Public Information Disclosure in Open Government Towards Good Governance. Jurnal Rechtsvinding, Vol.1 (1).

Lintartika, G. (2017, Januari 22). Ini Lho Keistimewaan Hutan Pinus dan Kebun Petik Apel di Tutur Pasuruan. Tribun News. Diakses dari http://www.surabaya.tribunnews.com.

Qureshi, S. (2014). Lesson From The Age of Nelson Mandela: Information And Communication Technology In The Quest Of Equality, Freedom And Justice. Journal of Information Technology for Development, Vol. 20 (1).

Retnowati, F. (2012). Keterbukaan Informasi Public dan Good Governance: Antara Das Sein dan Das Sollen. Perspektif, Vol. XVII, No.1.

Data internal Desa Gendro (2017).

http://www.berdesa.com/

http://www.pasuruankab.go.id 